\title{
Generating Electricity Using Microbial Fuel Cell Powered by Benthic Mud Collected From Two Locations in Akure, Nigeria
}

\author{
Adegunloye, D. V \\ Department of Microbiology, School of Sciences, Federal University of \\ Technology Akure, P.M.B 704, Akure, Ondo state, Nigeria. \\ Biological Sciences, Faculty of Basic and Applied Sciences, Elizade \\ University, Ilara- Mokin, Ondo state, Nigeria.

\section{Olotu, T. M} \\ Department of Microbiology, School of Sciences, Federal University of \\ Technology Akure, P.M.B 704, Akure, Ondo state, Nigeria.
}

doi: 10.19044/esj.2017.v13n18p242 URL:http://dx.doi.org/10.19044/esj.2017.v13n18p242

Abstract

Generating electricity using microbial fuel cell powered by benthic mud collected from two locations in Akure was carried out. The locations were Riverbed of FUTA and Apatapiti area of Akure. This was achieved by building anode and cathode containers connected together by a salt bridge and an external circuit was made to transfer the electrons from the anode to the cathode. Bacteria and fungi were isolated from the benthic mud for eight days using standard microbiological techniques. Lactobacillus plantarum, Escherichia coli, Bacillus subtilis, Enterobacter aerogenes, Trichoderma sp, Mucor sp and Alterania sp; Lactobacillus plantarum, Escherichia coli, Pseudomonas aeruginosa, Bacillus subtilis, Myrothecium sp and Geotrichum candidum were bacteria and fungi isolated from the benthic mud of Apatapiti area and Riverbed of Futa, Akure respectively. This was used for the generation of electricity using unsterilized mud sample and the control setup was sterilized mud from same source. The set-up was monitored every 24 hrous to determine the voltage and current generated. The $\mathrm{pH}$, concentration and temperature were measured. The temperature remains constant throughout the experiment. The set-up were operated at a normal temperature of $27^{\circ} \mathrm{C}$ and $29^{\circ} \mathrm{C}$ for Riverbed of FUTA and Apatapiti area of Akure respectively. The peak voltage was between $182.5 \mathrm{~V}$ and $192.5 \mathrm{~V}$ and current produced from the main set-up was between $0.3 \mathrm{~A}$ to $0.53 \mathrm{~A}$ for Futa river bed while for Apatapiti area of Akure the peak voltage and current were 192.5V and 0.3A respectively. Higher microbial population, current and voltage were observed to be generated in River bed of Futa than Apatapiti 
area. The difference in the voltage and current and the control set-up shows that anaerobic microorganisms are capable of producing electricity from microbial fuel cell under appropriate conditions.

Keywords: Benthic mud, Electricity, Generating and Microbial

\section{Introduction}

A microbial fuel cell is a device that converts chemical energy to electrical energy by the catalytic reaction of microorganisms. The microbial fuel cell is also a bio-electrochemical system in which bacteria are used to convert organic material into electricity. Production of electrical energy using microorganisms through microbial fuel cells (MFC) is one such renewable and sustainable technology that is considered to be one of the most efficient (HaoYu et al., 2007; Salgado, 2009) and carbon neutral energy sources (Lovley, 2006). MFCs are fuel cells that are capable of converting chemical energy available in organic substrates into electrical energy using bacteria as a biocatalyst to oxidize the biodegradable substrates (Schwartz, 2007). Microbial fuel cell (MFC) uses microorganisms to oxidize organic or inorganic matter and directly convert chemical energy into electrical energy (Koeneel et al., 2005; Anand et al., 2013 and 2015). Global energy demands continue to grow rapidly as a result of population growth and accelerating economic growth. Worldwide, net electricity generation, for example, is projected to reach 33.3 trillion kilowatt-hrs in 2030, about 1.9 times of that in 2005 and $88 \%$ of this demand is currently being met by fossil fuels (coal, oil and natural gas). Electricity generation relies mainly on nonrenewable fossil fuels such as coal and natural gas, which provide for over $60 \%$ of the total demand (Rittmann, 2006). Currently, combustion of such fossil fuel to produce electrical energy is adding about 6 gigatons of $\mathrm{CO}_{2}$ to the atmosphere every year. If this rate of $\mathrm{CO}_{2}$ released continues till 2100, the resulting temperature rise at $3^{0} \mathrm{C}$ over current levels is believed to bring catastrophic damage to the planet (Rittmann, 2008). Continued dependence of human and fossil fuel poses three major risks to humans. The first one is the possibility of rapid depletion of the natural fossil fuel reserves due to increased rate of consumption. The second one is geopolitical and economic upsets resulting from dwindling resources. The third is global climate change resulting from 1 net increase of atmospheric $\mathrm{CO}_{2}$ due to combustion of carbon-rich fossil fuels. In recent years, microbial fuel cells (MFCs) have been proposed as one of the promising alternative technologies for producing electricity directly from organic feed-stocks (Rittmann 2008). In a microbial fuel cell (MFC), electricity is produced directly from organic feed-stocks through complex biological, electrochemical and electrical reactions. It is relatively new biotechnological that is quite different from the traditional 
biotechnologies. The objectives of this research are firstly to isolate and determine of the microorganisms present in the benthic mud before and after the generation of electricity. Secondly to evaluate the feasibility of using benthic mud as energy source as well as a source for microbial cultures to produce electricity in MFCs.

\section{Materials and methods Materials}

Anode and cathode containers made from round-sided plastic containers (2) were purchased at Isikan Market Akure, compression fittings, ruler, drill press to make holes in theplastics and adhesive (PVC gum). The electrodes were made of carbon rods obtained from dry cell batteries (2), copper wire (12-guage), digital multimeter with leads having millivolts range, and soldering iron. Materials used in making the salt bridge were petri dishes, aluminum foil, measuring cylinder, tap water, pot, spoon, stove , weighing balance, agar $(30 \mathrm{~g})$, table salt ( $6 \mathrm{~g}$ and $1 / 2$ tbsp), refrigerator.

\section{Sample collection}

The rich mud sample was gotten from a lower stream that has a rich riverbed in both Futa riverbed and Apatapiti, Akure. A clean shovel was used to scoop the dip portion of the stream making sure that the sample gotten was not full of rocks but just rich mud. The stream water was also collected. The benthic mud sample was used within 24 hours after collection.

\section{Building of the anode and cathode containers}

The anode and cathode containers were built by drilling holes on both sides of the containers making sure that the holes were exactly opposite each other. After which a short PVC pipe was inserted into the holes of the two containers and PVC gum mixed with cement was then used to hold the pipe and the container together to avoid leakage. After drying, the end cap and the long PVC pipe were screwed in tightly and firmly and were screwed in also in the second pair of container. Holes which were two millimeters $(\mathrm{mm})$ in diameter were drilled on top of the two plastic containers lids. This set-up was filled with water past the holes/joints and allowed to stay overnight to check for the leakages and water tightness, plates 1 .

\section{Making the bridge}

Thirty grams of nutrient agar was weighed and added into a pot of boiling water, stirred until it was dissolved. Once dissolved, six grams of salt was weighed and mixed with the agar until it was dissolved. While the solution was still warm, it was poured into the compression tube covered at one end with 
aluminum foil. Once the tube was filled and stable for 10 minutes, the Petri dish was carefully moved to the refrigerator.

\section{Testing the fuel cell}

The external circuit for the electrons to move through was made. This was done by taking one end of the copper wire with a lower gauge and clipping to the bare end of the electrode coming from the anode. The other end of the copper wire was then clipped to the free end of a 3.3 mega-ohms resistor. One end of a copper wire was clipped to the free end of the resistor and the other end of the copper wire was clipped to the bare end of the electrode coming from the cathode. The voltage between the anode and the cathode was tested with the digital multimeter and the voltage read across the resistor was $9.1 \mathrm{mV}$.

\section{Discussion and result}

Table 1 and 2 are showing the bacterial and fungal population in the benthic and sterile benthic mud within the period of 192 hours for Apatapiti area and Riverbed of Futa. The bacterial and fungal population ranged from $(1.88 \mathrm{x}$ $10^{3}$ to $2.57 \times 10^{3} \mathrm{cfu} / \mathrm{ml}$ and $1.8 \times 10^{3}$ to $\left.1.6 \times 10^{3} \mathrm{sfu} / \mathrm{ml}\right)\left(2.25 \times 10^{3}\right.$ to $5.25 \mathrm{x}$ $10^{3} \mathrm{cfu} / \mathrm{ml}$ and $1.5 \times 10^{3}$ to $3.25 \times 10^{3} \mathrm{sfu} / \mathrm{ml}$ ) of bacteria and fungi for Apatapiti area and Riverbed of Futa respectively. Microorganism was not observed in the sterilized bethic mud in both Apatapiti area and Riverbed. Figures 1 and 2 shows the illustration of voltage and current generation while Figures 3 and 4 show the graphical illustration of $\mathrm{pH}$ and concentration for both Apatapiti and Riverbed of Futa. In figure 1 the voltage increased from 18.3 to $192.5 \mathrm{~V}$ and 84.5 to $182.5 \mathrm{~V}$ at $24 \mathrm{hrs}$ to $192 \mathrm{hrs}$ for Apatapiti and Riverbed of Futa respectively. In figure 2, the current increase from $1 \times 10^{8}$ to $3 \times 10^{8}$ Ampere at $24 \mathrm{hrs}$ to $336 \mathrm{hrs}$ for Apatapiti area. In Riverbed of Futa, the current increased from $1 \times 10^{8}$ to $5 \times 10^{8}$ at $24 \mathrm{hrs}$ to $264 \mathrm{hrs}$ and later decreased to $3 \times 10^{8}$ at $336 \mathrm{hrs}$. In figure 3 , the concentrations were maintained at 0.32 to 0.97 and 0.53 to 0.87 for Apatapiti and Riverbed of Futa respectively. The $\mathrm{pH}$ was neutral all through the experiment at both locations. All the parameters for the experiment were observed at constant temperature of $29^{\circ} \mathrm{C}$ and $27^{\circ} \mathrm{C}$ for Apatapiti area and River bed of Futa. 


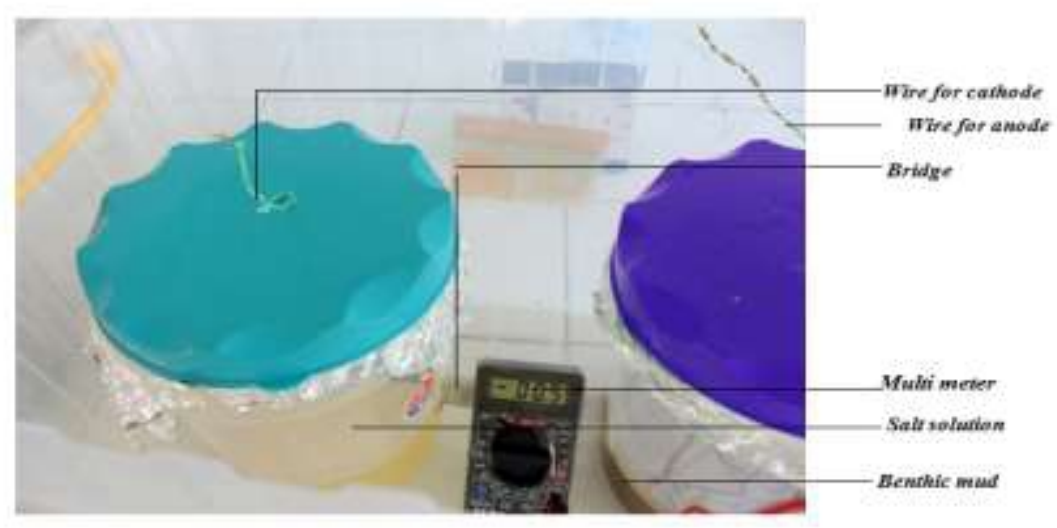

Plate 1: Set up of a microbial fuel cell powered by a mud and salt solution

Table 1: Microbial population of the benthic mud and sterilized sample from Apatapiti area for a period of eight days

\begin{tabular}{|l|l|l|l|l|}
\hline $\begin{array}{c}\text { Duration } \\
\text { (hours) }\end{array}$ & $\begin{array}{c}\text { Benthic mud } \\
\text { Bacteria } \\
\text { (cfu/ml) }\end{array}$ & $\begin{array}{c}\text { Benthic mud } \\
\text { fungi (sfu/ml) }\end{array}$ & $\begin{array}{c}\text { Sterilized mud } \\
\text { Bacteria } \\
(\mathbf{c f u} / \mathbf{m l})\end{array}$ & $\begin{array}{c}\text { Sterilized mud } \\
\text { fungi sfu/ml) }\end{array}$ \\
\hline 0 & $2.57 \times 10^{3}$ & $1.6 \times 10^{3}$ & 0 & 0 \\
\hline 48 & $3.16 \times 10^{3}$ & $2.9 \times 10^{3}$ & 0 & 0 \\
\hline 96 & $4.03 \times 10^{3}$ & $3.3 \times 10^{3}$ & 0 & 0 \\
\hline 144 & $4.69 \times 10^{3}$ & $4.6 \times 10^{3}$ & 0 & 0 \\
\hline 192 & $5.02 \times 10^{3}$ & $5.4 \times 10^{3}$ & 0 & 0 \\
\hline 240 & $4.13 \times 10^{3}$ & $4.1 \times 10^{3}$ & 0 & 0 \\
\hline 288 & $3.71 \times 10^{3}$ & $2.3 \times 10^{3}$ & 0 & 0 \\
\hline 336 & $1.88 \times 10^{3}$ & $1.8 \times 10^{3}$ & 0 & 0 \\
\hline
\end{tabular}

Table 2: Microbial population of the benthic mud sample from River bed of FUTA area for a period of fourteen days

\begin{tabular}{|l|l|l|l|l|}
\hline $\begin{array}{c}\text { Duration } \\
\text { (hours) }\end{array}$ & $\begin{array}{c}\text { Benthic mud } \\
\text { Bacteria } \\
\text { (cfu/ml) }\end{array}$ & $\begin{array}{c}\text { Benthic mud } \\
\text { fungi (sfu/ml) }\end{array}$ & $\begin{array}{c}\text { Sterilized mud } \\
\text { Bacteria } \\
\text { (cfu/ml) }\end{array}$ & $\begin{array}{c}\text { Sterilized mud } \\
\text { fungi sfu/ml) }\end{array}$ \\
\hline 0 & $5.25 \times 10^{3}$ & $3.25 \times 10^{2}$ & 0 & 0 \\
\hline 48 & $5.05 \times 10^{3}$ & $3.05 \times 10^{2}$ & 0 & 0 \\
\hline 96 & $4.57 \times 10^{3}$ & $2.85 \times 10^{2}$ & 0 & 0 \\
\hline 144 & $3.83 \times 10^{3}$ & $2.55 \times 10^{2}$ & 0 & 0 \\
\hline 192 & $3.35 \times 10^{3}$ & $2.31 \times 10^{3}$ & 0 & 0 \\
\hline 240 & $2.74 \times 10^{3}$ & $1.9 \times 10^{3}$ & 0 & 0 \\
\hline 288 & $2.51 \times 10^{3}$ & $1.7 \times 10^{3}$ & 0 & 0 \\
\hline 336 & $2.25 \times 10^{3}$ & $1.5 \times 10^{3}$ & & 0 \\
\hline
\end{tabular}

Table 3: Microorganisms isolated from the benthic mud at Apatapiti area and Riverbed of Futa

\begin{tabular}{l|l|l} 
Location & Bacteria & Fungi
\end{tabular}




\begin{tabular}{|c|c|c|}
\hline Apatapiti area & $\begin{array}{c}\text { Lactobacillus plantarum, } \\
\text { Pseudomonas aeruginosa, } \\
\text { Escherichia coli, Bacillus } \\
\text { subtilis and Enterobacter } \\
\text { aerogenes }\end{array}$ & $\begin{array}{c}\text { Trichoderma } \mathrm{sp}, \text { Mucor } \mathrm{sp} \\
\text { and Alterania } \mathrm{sp}\end{array}$ \\
\hline Riverbed of Futa & $\begin{array}{c}\text { Escherichia coli, } \\
\text { Lactobacillus } \text { plantarum } \\
\text { and Bacillus subtilis }\end{array}$ & $\begin{array}{c}\text { Myrothecium } \mathrm{sp} \text { and } \\
\text { Geotrichum candidum }\end{array}$ \\
\hline
\end{tabular}

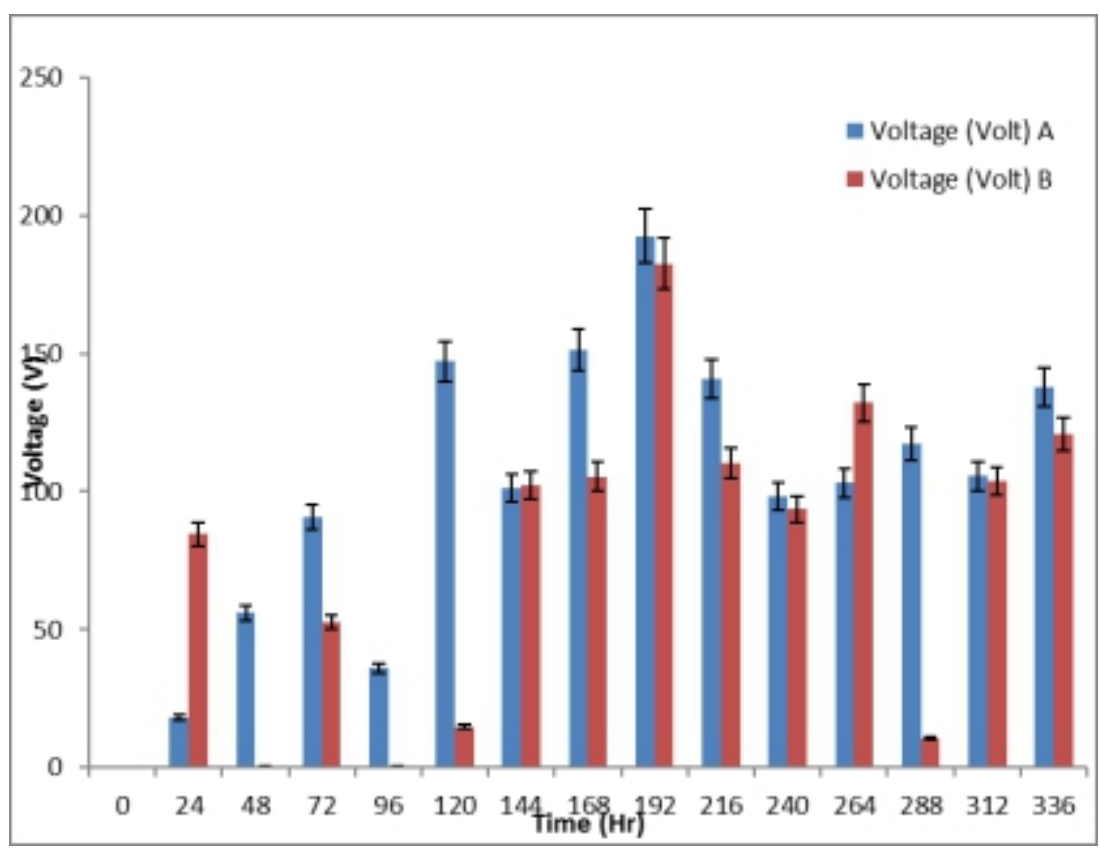

Figure 1: Volatge generation of benthic mud in the microbial fuel cell from Apatapiti (A) area and Riverbed of FUTA (B)

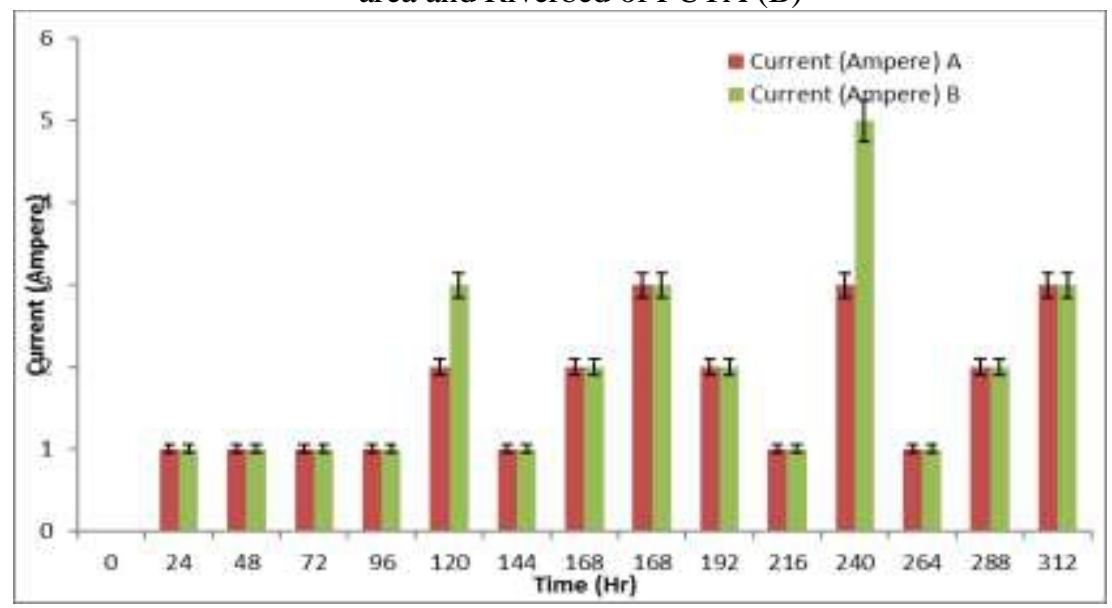

Figure 2: Current generation of benthic mud in the microbial fuel cell from Apatapiti (A) area and Riverbed of FUTA (B) 


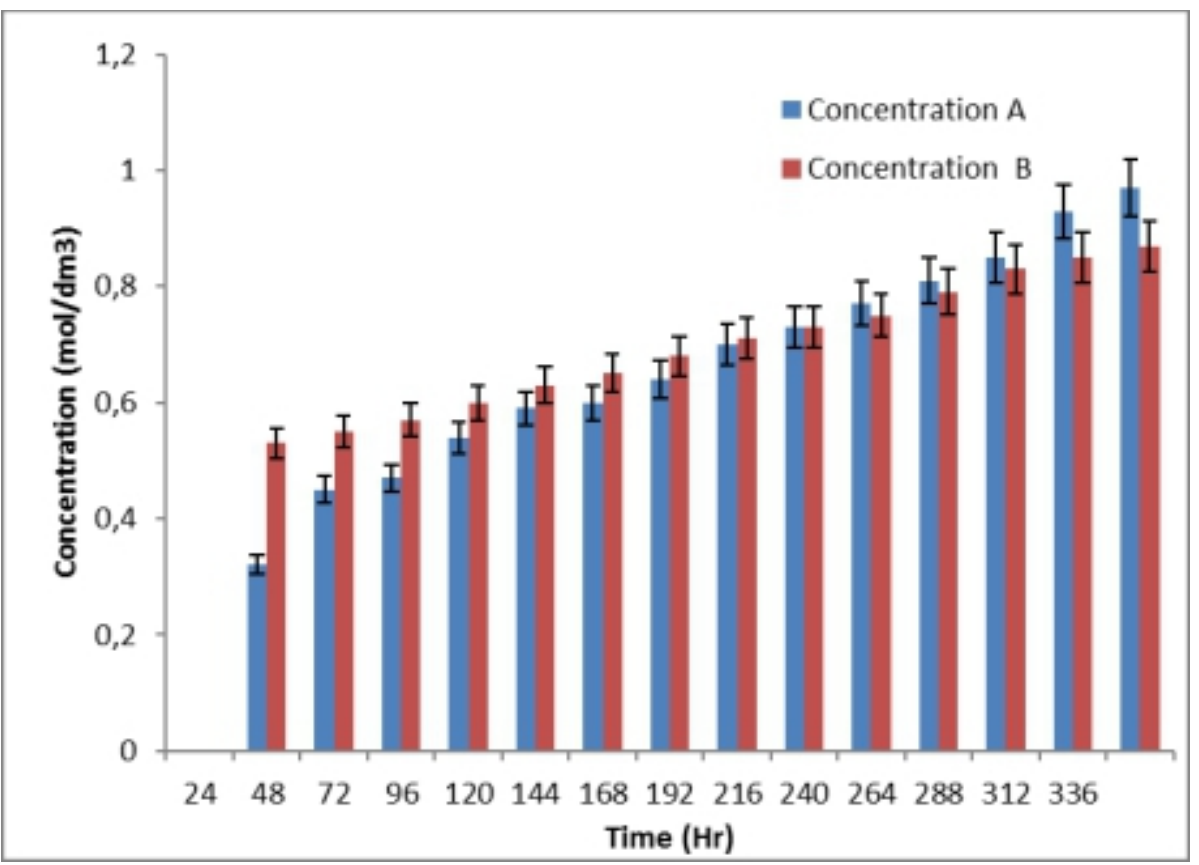

Figure 3: Concentration generation of benthic mud in the microbial fuel cell from Apatapiti (A) area and Riverbed of FUTA (B)

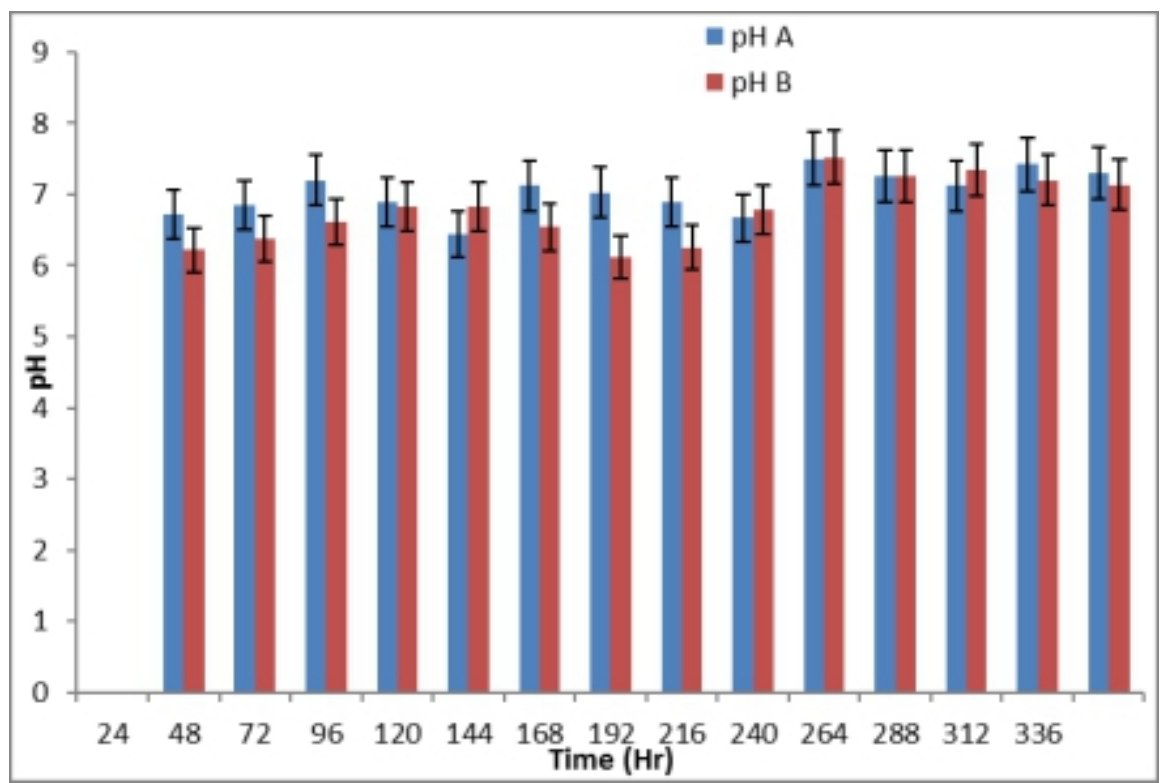

Figure 4: $p H$ generation of benthic mud in the microbial fuel cell from Apatapiti (A) area and Riverbed of FUTA $(B)$.

Exoelectrogenic bacteria in the sediment transfer electrons produced during the oxidation of organic matter to the anode electrode, while oxygen is reduced in the water column by accepting electrons from the cathode 
electrode as a result an electric current is generated (Logan, 2009). The set-up in this experiment which is the microbial fuel cell confirms that the microorganisms isolated were lactobacillus plantarum, Pseudomonas aeruginosa, Escherichia coli, Bacillus subtilis, Enterogenes aerogenes and Lactobacillus plantarum, Bacillus subtilis Escherichia coli, Lactobacillus plantarum, Trichoderma sp, Mucor sp, Alterania sp Myrothecium sp and Geotrichum candidum (Table 3) from the benthic mud from the two locations (Apatapiti area and Riverbed of Futa) are capable of producing electrons while feeding on and oxidizing the organic and inorganic matter in the mud. Microorganisms can accept electrons from an electrode and reduce organic and inorganic compounds. The oxygen accepts the electrons from the cathode and produces electric current. It was observed that the Riverbed of Futa benthic mud have higher bacterial and fungal population than Apatapiti area. The microbial populations were higher at $192 \mathrm{hrs}$ of the experiment and lower at 336hrs for the two locations (Table 1 and 2). The higher microbial growth observed might be due to the rich content of this mud at this period which increase rate of the microbial multiplication and the decrease in the microbial population at $336 \mathrm{hrs}$ could be due to utilization of the available nutrient in the mud by the microorganism which probably might have caused a drastic reduction in the microbial growth. The benthic mud from River bed of Futa has higher microbial population than Apatapiti mud which might have been it having higher nutrient which support more growth of microorganisms which in turn will produce higher current and voltage. Higher voltage and current were observed to be generated from the mud from River bed of Futa than Apatapiti area which could have resulted from the higher microbial growth observed from the location (Table 1 and 2) which probably aided more current and voltage to be produced. The high voltage and current generation in the microbial fuel cell from the two locations compared to the low voltage and current generation in the control microbial fuel cell (sterile benthic mud as substrate) indicates that microorganisms present in the benthic mud is capable of producing electrons which are used in the generation of electricity

\section{Conclusion}

Microbial fuel cell operates at a lower temperature and yield less biomass unlike anaerobic treatment which is often thought of as being slow, need more concentrated substrates and temperatures to operate effectively. This study shows that microbial fuel cell can generate electricity therefore, it is a form of bio-energy that can be exploited to reduce the effect of utilizing non-renewable fuel for energy. Higher current and voltage were observed to be generated in River bed of Futa than Apatapiti area, this might have resulted from higher microbial population observed at the in River bed of Futa than Apatapiti area. 


\section{References:}

1. Anand P, Shaheen A and Suhail AS. (2013),_Electricity generation from sewage sludge using environment friendly double chambered microbial fuel cell Sci. Int. 25(1):57-60

2. Anand P, Shaheen A and Suhail AS. (2015a), _Impact of agarose concentrations on electricity generation using hostel sludge based dual chambered Microbial fuel cell. Sci.Int. (Lahore) 27(2):10571061

3. HaoYu, E., Cheng, S., Scott, K., and Logan, B. (2007), _Microbial fuel cell performance with non-Pt cathode catalysts. Journal of Power Sources 171, 275-281

4. Korneel R and Verstraete W. (2005),_Microbial Fuel Cells: Novel Biotechnology for Energy Generation. Trends in Biotechnology 23:292-298

5. Logan, B.E. (2009), _Exoelectrogenic bacteria that power microbial fuel cells. Nat Rev Micro 7, 375-381

6. Lovley, D.R. (2006), _Bug juice: harvesting electricity with microorganisms. Nat Rev Micro 4, -508.

7. Rittmann, B (2008),_Opportunities for renewable bioenergy using microorganisms. Biotechnol. Bioeng. 100: 203-212

8. Salgado, C.A. (2009), _Microbial fuel cells powered by geobacter sulfurreducens. Basic Biotech vol 5, 5:1

9. Schwartz, K. (2007), _Microbial fuel cells: Design elements and application of a novel renewable energy sources. Enzyme and Microbial Technology, 47: 179-188 